\title{
MARKET KNOWLEDGE AND NEW PRODUCT PERFORMANCE: THE MEDIATING EFFECTS OF NEW PRODUCT CREATIVITY
}

\author{
Dariusz DABROWSKI ${ }^{*}$ \\ Marketing Department, Faculty of Management and Economics, \\ Gdansk University of Technology, Gdańsk, Poland
}

Received 31 July 2018; accepted 05 July 2019

\begin{abstract}
Market knowledge is recognised as an important predictor of new product performance, which existing studies have proven. However, a missing link in this relationship is creativity, and specifically, as a natural process in product innovation. This study aims to examine a model that includes two mediating mechanisms between market knowledge scope and two new product outcomes, respectively: a new product's competitive advantage and its commercial success. In both cases two mediators are used that represent dimensions of creativity - i.e. a product's meaningfulness and novelty. The model was tested on a sample of 374 Polish medium-high- and high-technology companies using structural equation modelling. The results indicated that market knowledge is transferred to both new product outcomes through new product creativity, albeit somewhat differently. The first mediating mechanism, which explains the factor of competitive advantage, operates only through the indirect effects of both the product's meaningfulness and its novelty. The second mechanism works directly, through the market knowledge's effect on commercial success, as well as indirectly, through product meaningfulness. Subsequently, theoretical and managerial implications as well as indications for future research are provided based on these findings.
\end{abstract}

Keywords: market knowledge, creativity, product novelty, product meaningfulness, product performance, competitive advantage, innovation, mediation, new product, high technology.

JEL Classification: M10, M31, O30.

\section{Introduction}

Currently, new product development (NPD) is a crucial area for any company due to customers' increasing needs, intense competition, and technology development (Crawford \& Di Benedetto, 2011). However, the NPD field is both costly and risky. According to a recent survey from the Product Development and Management Association, companies spend approximately 12 per cent of sales on NPD - a large amount - although 39 per cent of launched

*Corresponding author. E-mail: dariusz.dabrowski@zie.pg.gda.pl 
products still fail (Lee \& Markham, 2016). This is because several uncertainties emerge when developing new products. For instance, six risk types were identified in products based on high technology (Dhebar, 2016), one of which is significant market uncertainty. As new product outcomes are uncertain, numerous studies have searched for the determinants of new product success; their results have been summarised in a meta-analysis (Evanschitzky, Eisend, Calantone, \& Jiang, 2012; Henard \& Szymanski, 2001; Montoya-Weiss \& Calantone, 1994). The meta-analysis results reveal that a firm's knowledge is a significant antecedent of product innovation performance. Hence, researchers began to probe for more details regarding the different aspects of knowledge relative to NPD success. Some examples of the knowledge base drivers of new product performance are as follows: market knowledge competence (Atuahene-Gima \& Wei, 2011; Claudy, Peterson, \& Pagell, 2016; Li \& Calantone, 1998), exploiting external knowledge sources (Ferreras-Méndez, Newell, Fernández-Mesa, \& Alegre, 2015), knowledge management (Lin, Che, \& Ting, 2012), market knowledge dimensions (De Luca \& Atuahene-Gima, 2007; Jin, Shu, \& Zhou, 2019; López-Cabarcos, Srinivasan, GöttlingOliveira-Monteiro, \& Vázquez-Rodríguez, 2019), and knowledge integration mechanisms (De Luca \& Atuahene-Gima, 2007; Guo, Cai, \& Fei, 2019) or network-based market knowledge (Bao, Sheng, \& Zhou, 2012). Knowledge is important in managing an organisation, and is recognised as another non-traditional production factor as well as a crucial resource for economic growth (Ginevičius \& Korsakiene, 2005). This study can be included among studies on knowledge - NPD performance, as it concentrates on market knowledge scope - or the breadth and depth of knowledge about customers, competitors and other market aspects -as a crucial predictor of performance.

A company's market knowledge is primarily the effect of the firm's strategic orientation on the market (Yuan \& Chen, 2015), in that a company creates a culture and climate (Narver \& Slater, 1990; Ozkaya, Droge, Hult, Calantone, \& Ozkaya, 2015) that focuses on its customers, competitors, and overall market situation. If a company is market-oriented, it aims to continuously create superior value for its customers by understanding them and its competitors (Narver \& Slater, 1990). Further, market understanding results in market knowledge (Ozkaya et al., 2015), which is consequently an important predictor of new product success (Cooper, 2019).

However, empirical evidence exists that market knowledge or market-learning activities positively impact product innovation performance (Atuahene-Gima, 1995, 2005; De Luca \& Atuahene-Gima, 2007; Li \& Calantone, 1998; Lin et al., 2012; Zhang, Wu, \& Cui, 2015), but this occurs from the application of market knowledge in different areas of an NPD project. One of these areas is creativity (Amabile \& Pratt, 2016; Stankevičienè, Levickaitė, Braškute, \& Noreikaite், 2011), which this work assumes to mediate the relationship between the scope of market knowledge and new product outcomes. Market knowledge and creativity are necessary resources for efficient NPD in a market economy (Atuahene-Gima \& Wei, 2011), and, thus, understanding these mediation processes is important. Hence, this study will answer the following general research question: Does new product creativity mediate the relationship between market knowledge scope and product innovation outcomes? In this way, this work will address a research gap recently indicated by Kim, Im, and Slater (2013), who called for further research on knowledge about customers and competitors in the contexts of new 
product creativity and product performance. Moreover, a recent work by Nakata et al. (2018) on the antecedents and consequences of new product creativity called to investigate other potential antecedents of new product creativity, as their work focused on such factors as market orientation, leadership, and national culture.

The overall purpose of this work involves investigating the mediating effects between market knowledge scope and new product performance through new product creativity. Specifically, this study focuses on two mediating mechanisms - first, between the scope of market knowledge and a new product's competitive advantage; and second, between the scope of this knowledge and a new product's commercial performance. The two mediators in both situations are applied to explain the relationships of interest. These mediators express distinct aspects of new product creativity: a new product's meaningfulness and novelty. To the best of our knowledge, no study has examined these mechanisms by testing indirect, direct and total effects. A literature review confirms this through the use of substantial keywords - "market knowledge", "creativity" and "performance" - in the abstracts, titles and keywords found in the Scopus database. Only one publication by Atuahene-Gima and Wei (2011) resulted from this search, but it did not investigate the mediating effects and did not address the research gap of our study. Additionally, a similar literature review was performed with the Web of Science, Elsevier Science Direct, Taylor and Francis, and IEEE databases, among others. Only the Web of Science, Ebsco, and Wiley generated results, one of which was the study by Atuahene-Gima and Wei (2011); several additional journal papers and conference proceedings were found, but none addressed our research problem.

This research contributes to existing literature in several ways. First, this work aims to explain not only how the market knowledge of a potential new product transforms into its competitive advantage, but also the manner in which this knowledge transfers to commercial success, in both cases through product creativity. No study thus far has tested these indirect effects. Second, this study is the first attempt to illustrate these two mechanisms' structural differences, as a product's commercial success implies a different, broader meaning than competitive advantage. Third, the research will compare the overall strength of the market knowledge's impact on two new product outcomes. Consequently, we will also present managerial recommendations for using market knowledge in NPD to achieve high competitive advantage and commercial success.

The remainder of this paper is organized in the following way. First, we begin by defining the key terms and specifying the theoretical background of the study. Second, we present the conceptual framework and develop hypotheses on the scope of market knowledge, the two dimensions of new product creativity, and new product competitive advantage and its commercial performance. Third, after discussing the sample, measurement and data analysis issues, we provide the results. The paper ends with a discussion of the results, managerial implications, limitations and future research directions.

\section{Theoretical background}

Market knowledge is defined as the knowledge of prospective customers and competitors, as well as other market aspects related to a given product category (De Luca \& Atuahene-Gima, 
2007). This type of knowledge is crucial at each stage of the NPD process, as the market economy paradigm posits that a firm should shape its products and services to provide superior value for customers. This can be achieved by the continuous monitoring and understanding of customers' problems as well as competitors' solutions to them. Market knowledge in NPD is essentially applied to create a superior new product, and to develop superior operations related to the product, such as promotional programs. This knowledge can be categorised into several dimensions - for example, breadth, depth, tacitness or specificity (De Luca \& Atuahene-Gima, 2007; Kim et al., 2013). However, this work uses a holistic approach by focusing on the overall scope of market knowledge possessed by professionals engaged in NPD. This parallels current managerial practices, as they use all available market knowledge in NPD.

According to Amabile and Pratt (2016, p. 158), creativity is defined as the "production of novel and useful ideas by an individual or small group of individuals working together". This definition is relevant to this study for two reasons. First, the definition takes an output perspective to determine creativity. It can be said that an action is creative if the resulting output is creative. As this perspective is straight and allows the assessment of a result, and so is quite commonly used in both social (e.g. Amabile, 1982) and management sciences (e.g. Andrews \& Smith, 1996; Im, Hussain, \& Sengupta, 2008). This output perspective can be adapted to new products (e.g. Im, Montoya, \& Workman, 2013; Im \& Workman, 2004; Slater, Hult, \& Olson, 2010), as the product itself is a result of the NPD process. Second, the definition reveals two specific features of creative output. A creative new product is first defined by its novelty or uniqueness to potential buyers, and second, by its usefulness or appropriateness to these buyers compared to other competitive products. Bruner's (1962) observation can be paraphrased to indicate a creative new product evokes an "effective surprise" in the customer, along with a "shock of recognition" that, although novel, is entirely appropriate.

The two new product outcomes this study investigates are a new product's commercial performance and competitive advantage. The former refers to the degree to which a new product meets its market and financial goals (Montoya-Weiss \& Calantone, 1994), which are expressed in terms of financial (e.g. sales) and market-share objectives (Hertenstein \& Platf, 2000). A product's competitive advantage is defined as the degree to which customers perceive greater value in a company's product compared to anything offered by its rivals (Atuahene-Gima \& Wei, 2011; Im, Montoya, \& Workman, 2013; Montoya-Weiss \& Calantone, 1994). In the latter case, a new product released by a given firm is compared with competitive items in terms of several dimensions, such as function, quality, or product differentiation. These two outcomes were selected because they are likely to be determined by both the scope of market knowledge and new product creativity (Im et al., 2013; Kim et al., 2013).

This study's theoretical background is the resource-based view (RBV) of a firm (Barney, 1991; Wernerfelt, 1984). The RBV postulates that if a firm possesses specific resources - such as those that are valuable, rare, inimitable and non-substitutable - then these can be uniquely configured to achieve competitive advantage and high performance over time (Barney, 1991). Further, market knowledge and creativity can both be considered as such resources in NPD. First, market knowledge is an intangible, valuable asset, as this knowledge can be used to 
develop new products that aim to satisfy customer needs and challenge competitors. This knowledge is rare and difficult to imitate due to its complexity, as it covers broad, different market aspects, and its origin, as it stems from experience, education, individual skills, and capabilities. Further, this knowledge is irreplaceable.

Second, creativity is a valuable, non-substitutable resource in NPD because it is a necessary condition for each innovation (Amabile \& Pratt, 2016). Further, Wade and Hulland (2004) divide resources into assets, or anything used in processes, such as machinery or equipment; and capabilities, or the patterns of actions used to transform assets into products. The latter also covers the purported "dynamic" capabilities that enable a firm to align with the changing organisational environment (Teece, Pisano, \& Shuen, 1997). Creativity, which allows firms to develop novel and useful products, can be regarded as a dynamic, rare and inimitable capability. Therefore, both market knowledge and creativity are regarded as firm-specific resources that enable positive new product outcomes.

\section{Conceptual framework and hypotheses}

The relationship between market knowledge and a product's competitive advantage can be grounded in Narver and Slater's (1990) concept of market orientation. These authors posit that market orientation provides an understanding of customers' expressed and latent needs; competitors' strengths and weaknesses, capabilities, and strategies; and other market aspects, such as market trends and mechanisms. This understanding is a source of market knowledge (Ozkaya et al., 2015) that leads to the creation of superior value for customers. Therefore, extensive market knowledge should result in a product with distinct competitive advantage, in that the firm can develop a new product that provides greater value for customers than its competitors. This can be accomplished by increasing the product's benefits for customers, for instance, by offering greater functionality or higher performance for some attributes (e.g. quality or appearance), or by decreasing the cost to the customer. This reasoning mirrors the RBV theory, as market knowledge is a company's specific asset; thus, it is argued that increasing market knowledge in NPD is associated with enhancing a new product's competitive advantage. Therefore, it may be expected that:

H1: The scope of market knowledge positively and directly affects a new product's competitive advantage.

The second relationship, between market knowledge and a new product's commercial performance, is supported by the belief that a product's commercial success depends on the product itself, but simultaneously on other actions associated with this product, such as its marketing campaign during the commercialisation stage. Currently, marketing support under typically intense global competition to convince customers to switch to something new is seemingly equally important as the new product itself. R. Ginevičius, Podvezko and A. Ginevičius (2013) demonstrated that marketing activities related to price, promotion or place have nearly the same importance as the product. Hence, market knowledge is necessary in NPD to develop superior new products and different operations that support them. Both elements relate to the product's commercial success; therefore, a direct link is likely to exist between market knowledge and the product's commercial success. De Luca and Atua- 
hene-Gima (2007) have discovered that dimensions of market knowledge - such as breadth, depth, and specificity - were positively linked to new product performance. Further, it may be expected that:

$\mathrm{H} 2$ : The scope of market knowledge positively and directly affects a new product's commercial success.

This study posits that, aside from direct relationships, indirect effects are derived from the following sequence: market knowledge scope affects product creativity, which subsequently affects new product outcomes. This sequence occurs due to the following reasons: First, the relationship between market knowledge and product creativity is based on the model of creativity and innovation as proposed by Amabile and Pratt (2016), which notes three crucial determinants of creativity: the intrinsic motivation to do the task, creativity-relevant processes, and the skills required for the task. The last factor is of interest in this study, and means "one's expertise or factual knowledge about the domain, technical skills for doing work and advancing one's knowledge in the domain, and special domain-relevant talents" (Amabile \& Pratt, 2016, p. 160). Specifically, market knowledge is one type of expertise that serves as an input for the creative processes or activities in NPD (Kim et al., 2013). Individual or group knowledge about prospective customers, competitors, and other market aspects in the new product category provides the crucial understanding required in launching meaningful and novel products. This reasoning parallels the RBV theory, as creativity is considered a dynamic, firm-specific capability. Therefore, it is assumed that greater market knowledge results in greater new product creativity, and is expressed in the product's novelty and meaningfulness. Second, greater new product creativity should lead to better product outcomes. If a firm can create a new product that is superior to its competitors' in terms of both meaningfulness and novelty, then its competitive advantage will be greater than its rivals' (Im et al., 2013). Hence, this line of reasoning supports the presence of the mediating effect, wherein market knowledge is likely to influence new product creativity, which, in turn, influences product competitive advantage. This mediating effect is represented in our work by two separate mediators that may operate in parallel for the following reasons. First, we introduce two mediators because the creativity construct has a dual nature. Two distinct dimensions of creativity (i.e. a product's meaningfulness and novelty) together characterize a creative output (Amabile \& Pratt, 2016; Im et al., 2013). According to Nakata and colleagues, "only something that is meaningful as well as novel can be characterized as creative - rather than bizarre" (Nakata et al., 2018, p. 942). Second, these two constructs of creativity do not have a temporal order and thus they do not causally influence each other (Nakata et al., 2018). In this situation, a parallel multiple mediator model reflects this phenomenon as opposed to the serial one in which the mediators are linked in a casual chain (Hayes \& Rockwood, 2017; Muthén, Muthén, \& Asparouhov, 2016). Therefore, the perspective of this study is that the effect of market knowledge scope is transmitted to new product competitive advantage through each dimension of creativity and that these two mediating processes operate simultaneously or "in parallel". Therefore, it is posited that:

H3: The scope of market knowledge positively and indirectly affects a new product's competitive advantage through the product's meaningfulness and novelty. 
Additionally, a new product's meaningfulness and novelty for customers will be the key determinants of its commercial performance. Product meaningfulness means that a product is perceived by customers as more useful, appropriate, or significant for them than competitive products (Kim et al., 2013). Therefore, increasing this dimension should result in a better fit of the product to the customers' needs and expectations, and, in turn, this better fit is likely to influence their buying decision. Existing studies showed the positive link between a product's meaningfulness and its market, as well as financial performance (Im \& Workman, 2004; Nakata et al., 2018). Further, a product's novelty expresses its uniqueness or originality in comparison to competitive products (Kim et al., 2013). This novelty is needed to arouse initial interest among customers and is likely to trigger their purchase intent; however, products with a very high level of novelty could make them unfamiliar to customers (Nakata et al., 2018). However, an important antecedent of new product creativity is the scope of market knowledge (Amabile \& Pratt, 2016). Knowing more than rivals about customers' needs and wants, competitive products, market mechanisms, and their trends should result in more useful as well as original product innovation. Therefore, the following mediating processes are substantially supported in NPD: the scope of market knowledge tends to influence positively both dimensions of new product creativity, and these are likely to have a positive effect on a new product's commercial performance. This mediation includes two mediators, namely new product meaningfulness and novelty, that work in parallel because they are not causally connected (Nakata et al., 2018). Therefore, the two simultaneous mediating mechanisms are again modelled by a parallel mediator model with two mediators (Hayes \& Rockwood, 2017; Muthén et al., 2016). Overall, the scope of market knowledge is transferred to a new product's commercial success at once through each of the constructs of new product meaningfulness and novelty. Hence, it is posited that:

H4: The scope of market knowledge positively and indirectly affects a new product's commercial success through the product's meaningfulness and novelty.

The set of four hypotheses developed and theoretically supported defines the conceptual framework of this study. Likewise, our conceptual model is inferred from the four hypotheses and illustrated in Figure 1. In this diagram, the ellipses represent the constructs under investigation and the single-headed arrows show a direct relationship between constructs. Our hypotheses are symbolically presented in Figure 1.

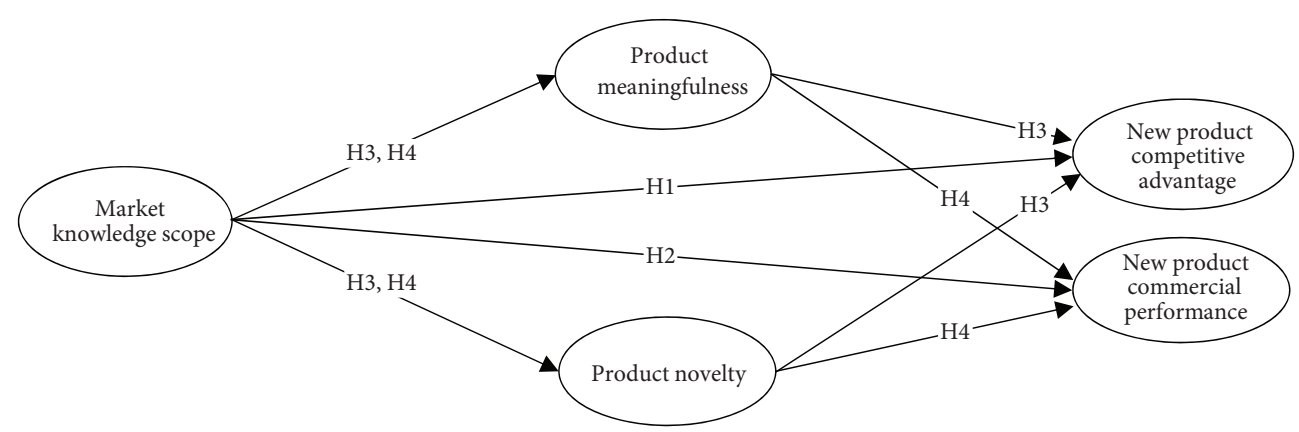

Figure 1. The conceptual model 


\section{Methods}

\subsection{Sample and procedure}

Empirical data for this study was collected from medium-high- and high-technology companies in Poland. Industrial sectors and manufacturers from member nations in the Organisation for Economic Co-operation and Development (OECD) are classified in the following four groups: high, medium-high, medium-low, and low technology. This classification is based on direct $\mathrm{R} \& \mathrm{D}$ intensity and the $\mathrm{R} \& \mathrm{D}$ embodied in intermediate and investment goods (Hatzichronoglou, 1997). Our study focuses on the former two groups, as they include industries with higher technological intensities than the latter two. These firms are suitable for this study as they face rapid technological and market changes that force them to monitor their environment and develop new products. The OECD's (2015) classification was used to identify high-tech and medium-high-tech industries based on their Nomenclature of Economic Activities (NACE) code. The first group contains such industries as the pharmaceutical (NACE code 21), computers and electronics (NACE code 26), and aerospace (NACE code 30.3 ) industries; the second group involves the chemical (NACE code 20), weapons and ammunition (NACE code 25.4), electrical industrial machinery (NACE code 27), machinery and equipment (NACE code 28), automotive (NACE code 29), other transport equipment (NACE code 30 excluding codes 30.1 and 30.3), and medical and dental equipment (NACE code 32.5) industries. Moreover, we focus on companies that employ more than 49 people or medium- and large-sized firms - as such firms are involved in NPD to a greater extent than smaller companies.

The HBI's directory of Polish firms was used to acquire a sampling frame of the target population. A simple random method drew 1,450 firms from the sampling frame due to budget constraints. Subsequently, a mail survey was conducted among these firms from April to June 2016. The questionnaire was accompanied by a cover letter that explained this study's objectives and assured confidentiality; a prepaid envelope was also included, and this packet was sent to the highest-ranked person in each company, such as the General Director. This person was asked to choose a new product that had been introduced to the market at least six months earlier, and to forward the questionnaire to the personnel engaged in this project, such as marketing, $R \& D$, or engineering professionals. A research report was offered as an incentive for firms that returned completed questionnaires. Additionally, two follow-up mailings were sent to improve the response rate. Of the questionnaires returned, 374 usable responses were received after discarding incorrect questionnaires, or a response rate of 25.8 per cent.

Both early and late respondents were then compared to assess any non-response bias (Armstrong \& Overton, 1977). The means for all constructs of interest were examined through a $t$-test, which revealed no significant differences in the mean for all constructs $(p<0.05)$ and provided evidence that no such bias exists.

Before conducting the survey, a pilot study was carried out among nineteen NPD practitioners who were selected from managerial students at the Gdansk University of Technology, Faculty of Management and Economics. The study was conducted face-to-face and participants were asked to remark on potential improvements after completing the questionnaire. 
The final sample was described in terms of industry type and company size; the sample included manufacturing companies, and specifically: machinery and equipment $(32.1 \%)$, electrical industrial machinery (16.0\%), motor vehicles $(15.2 \%)$, chemicals and chemical products $(14.2 \%)$, computer and electronic products $(10.4 \%)$, pharmaceutical products (4.3\%), other transport equipment (2.9\%), medical and dental products $(2.7 \%)$, air and spacecraft machinery (1.3\%), and weapons and ammunition (0.8\%). Of these companies, 75.9 per cent had 50 to 250 employees, while 20.1 per cent had 250 to 999 employees, and 4.0 per cent had more than 999 employees.

\subsection{Measurements}

The scope of market knowledge was measured with four items selected from the knowledge breadth and depth survey scales from Bao et al. (2012) and De Luca and Atuahene-Gima (2007). As operationalised in a previous study (Im et al., 2013), each of the two dimensions of new product creativity - the new product's novelty and meaningfulness - was measured with a four-item scale. A new product's competitive advantage was measured by three items selected from works by Atuahene-Gima (1995) and Im et al. (2013). A new product's commercial performance was operationalised through four items selected from works by Dabrowski (2018) and Hultink, Talke, Griffin, and Veldhuizen (2011). All items used in the constructs were measured on seven-point Likert-type scales, and are presented in the Appendix, Table A1.

\subsection{Data analysis}

Thus far, no consensus has been reached regarding the recommended sample size for structural equation modelling (SEM). However, according to Bentler and Chou (1987), a sample of 374 units can be considered as adequate for this research with regard to a model's complexity (i.e. five constructs) and essential characteristics.

A confirmatory factor analysis (CFA) was applied to test the measurement model, and SEM verified the research hypotheses with the use of Mplus v.8 statistical software. This software tests the mediation effects of two parallel multiple mediator models in one analysis, as recommended by Hayes and Rockwood (2017); this feature is relevant for this study. Additionally, the software provides a mean-adjusted maximum likelihood estimator (MLM), used in both CFA and SEM analyses, which is resistant to data non-normality (Muthén et al., 2016).

According to Baron and Kenny (1986 p. 1173), mediation is a "mechanism through which the focal independent variable is able to influence the dependent variable of interest". This mechanism includes one mediator variable $M$, which is causally located between an independent variable $X$ and a dependent variable $Y$ (Hayes \& Rockwood, 2017). Hence, in mediation $X$ affects $Y$ because $X$ influences $M$, which in turn affects $Y$. The sequence expressed in the form of $X \rightarrow M \rightarrow Y$ is called the "indirect effect". However, aside from its mediational relationship, $X$ can still immediately impact $Y$, expressed as $X \rightarrow Y$, which represents a direct effect. If the direct and indirect effects are aggregated, then the overall effect is assessed as $X$ on $Y$. Discovering the mediating mechanism is important because an explanation is then 
provided as to why and in which way $X$ impacts $Y$. If $X$ influences $Y$ through more than one mediator, several mediating mechanisms can be observed, which are represented by a multiple mediator model. If these mechanisms parallel, then such a phenomenon is represented by a parallel multiple mediator model (Jose, 2013).

This study's conceptual model is composed of two parallel multiple mediator models with the same independent variable (market knowledge) and mediators (product novelty and its meaningfulness), but their dependent variables differ: a new product's competitive advantage versus its commercial performance. Recommendations from Hayes and Rockwood (2017) were followed to estimate indirect effects in the conceptual model. First, we verify each indirect effect by testing the product of effects that create a given indirect effect. Second, we evaluate all effects in one model, both direct and indirect, because they operate simultaneously. Jose (2013) demonstrated that the best way to verify such a model is to use SEM; therefore, Mplus software was used. Further, the two mediators represent two aspects of the same domain - i.e. product creativity - and therefore share at least one omitted cause, such as intrinsic motivation to do the task. In this situation the residual covariance between the mediator variables was included in the model, as indicated in literature (Jose, 2013; Kline, 2012; Muthén et al., 2016).

\section{Results}

\subsection{Measurement model}

According to Anderson and Gerbing (1988), a measurement model must be tested before evaluating the conceptual model; we used a CFA involving the five constructs listed in the Appendix, Table A1. The initial model indicated an acceptable fit with the data: $\chi^{2}(160)=$ $342.553, p<0.001, \chi^{2} / \mathrm{df}=2.14$, RMSEA $=0.055$, SRMR $=0.050, \mathrm{CFI}=0.952$, and $\mathrm{TLI}=$ 0.943. A chi-square test was applied to evaluate the model's fit, but it has certain limitations, for example, a sensitivity to sample size (West, Taylor, \& Wu, 2012). Therefore, other fit indices as recommended for the MLM estimator were used to evaluate the model (West et al., 2012). The latter indices met the standards necessary for a good fit: a comparative fit index (CFI) value of 0.95 or higher, a root mean square error of approximation (RMSEA) value of 0.06 or less, a standardised root mean square residual (SRMR) value of 0.08 or less, as well as an $\chi^{2} / \mathrm{df}$ value of 5 or less (Hu \& Bentler, 1999; West et al., 2012). However, the required standard for the Tucker-Lewis index (TLI) value of 0.95 was not met (Hu \& Bentler, 1999).

Regarding convergent validity, it is recommended that factor loadings should be significant (Brown \& Moore, 2012) and their standardised values should be 0.4 or higher (Ford, MacCullum, \& Tait, 1986), and ideally 0.7 or higher (Merenda, 1997). A review of the factor loading estimates revealed that one item ("is not at all cost effective" versus "is highly cost effective") for the product's competitive advantage had a loading score of less than 0.6. After removing this item, the second measurement model provided a better fit to the data: $\chi^{2}(142)=279.946, p<0.001, \chi^{2} / \mathrm{df}=1.97, \mathrm{RMSEA}=0.051, \mathrm{SRMR}=0.040, \mathrm{CFI}=0.962$, and TLI $=0.954$. Further, all fit indices met the required standards. Hence, these items were retained; their standardised factor loadings and $t$-values are presented in the Appendix, Table A1. All items' factor loadings are highly significant and greater than 0.64 , and thus, adequate convergent validity is demonstrated. 
Table 1. Constructs' correlations

\begin{tabular}{|l|c|c|c|c|c|}
\hline \multicolumn{1}{|c|}{ Construct } & 1 & 2 & 3 & 4 & 5 \\
\hline 1. Market knowledge scope & 0.747 & & & & \\
\hline 2. Product meaningfulness & 0.507 & 0.825 & & & \\
\hline 3. Product novelty & 0.514 & 0.374 & 0.777 & & \\
\hline 4. Product competitive advantage & 0.285 & 0.340 & 0.487 & 0.810 & \\
\hline 5. Product commercial performance & 0.425 & 0.323 & 0.292 & 0.222 & 0.855 \\
\hline
\end{tabular}

Note: Off-diagonal: construct correlations; along-diagonal: square root of the AVE; all correlations are significant at $p<0.001$.

Table A1 in the Appendix demonstrates the construct reliabilities (CR) and average variance extracted (AVE). All CR values exceed the 0.7 critical value (Bagozzi \& Yi, 2012), and all AVE values are greater than the 0.5 threshold (Fornell \& Larcker, 1981). Table 1 presents the construct correlations and the square root of the AVE. According to Fornell and Larcker (1981), the constructs demonstrate discriminant validity, because the square root of the AVE for each factor exceeds the highest correlation between the factors involving the focal factor.

The correlations of the variables of interest may be affected by a common method variance (CMV), as these variables were simultaneously measured using a single instrument (Malhotra, Schaller, \& Patil, 2017). The CMV was controlled by applying both procedural and statistical techniques. The procedural techniques consisted of ensuring respondents' anonymity, placing constructs in different sections, reducing item ambiguity and improving the items' wording. Regarding the statistical analysis, Harmon's single-factor model was tested by applying a CFA to reveal this model fit the data poorly: $\chi^{2}(152)=2,136.354, p<0.0001$, RMSEA $=0.187, \mathrm{CFI}=0.453$, TLI $=0.385$, and SRMR $=0.140$. This indicates that a one-factor model is not acceptable, and that the CMV is unlikely to influence this study's results.

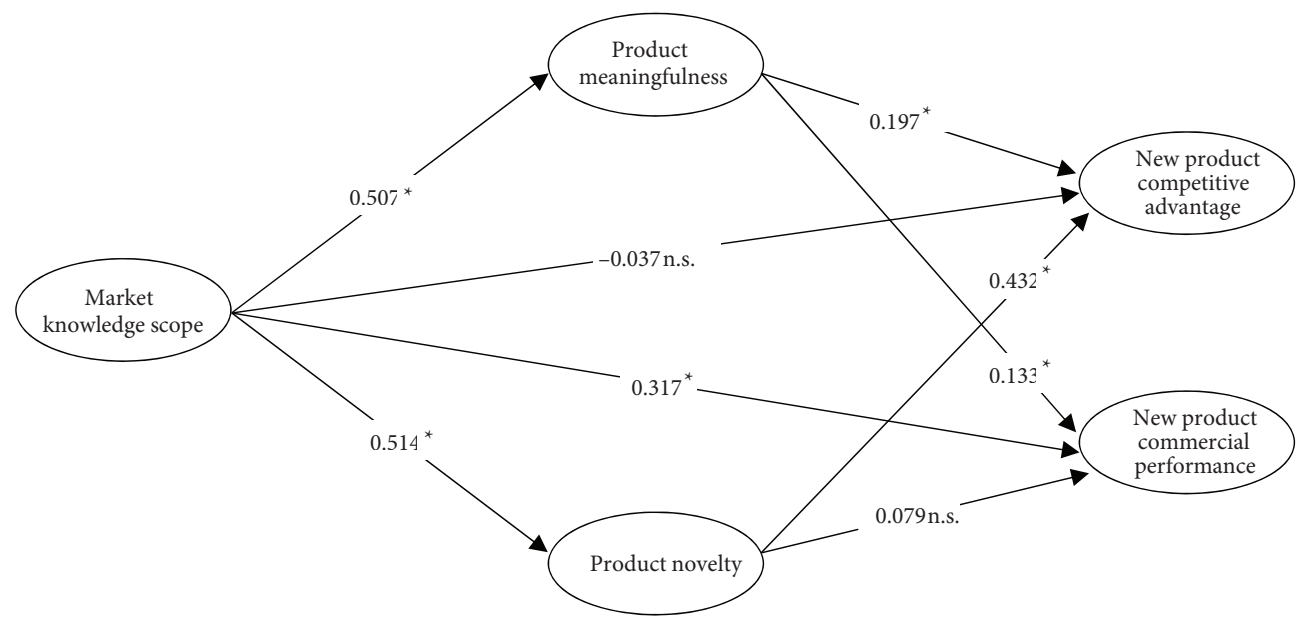

Note: Standardised values; an asterisk $\left(^{*}\right)$ indicates statistical significance at $p<0.05$; n.s. indicates statistical insignificance at $p>0.05$.

Figure 2. Estimation of the conceptual model 


\subsection{Hypothesis testing}

Figure 2 illustrates the structural model of market knowledge, marketing creativity and the two types of new product outcomes as well as the estimated effects, which provided a good model fit: $\chi^{2}(142)=279.946, p<0.001, \chi^{2} / \mathrm{df}=1.97, \mathrm{RMSEA}=0.051, \mathrm{SRMR}=0.040, \mathrm{CFI}=$ 0.962 , and TLI $=0.954$.

Table 2 demonstrates that, on the one hand, the scope of market knowledge did not have a significant, direct effect on a new product's competitive advantage $(\beta=-0.037, p>0.05)$, which contradicts our expectations (does not support Hypothesis 1); on the other hand, this had a significant, positive total indirect effect on the competitive advantage construct through a product's novelty and meaningfulness $(\beta=0.322, p<0.001)$, supporting Hypothesis 3 . Both parallel, specific indirect effects - which indicate the scope of market knowledge's overall indirect effect on a new product's competitive advantage - were significant and positive, through both new product meaningfulness $(\beta=0.100, p<0.01)$ and novelty $(\beta=0.222$, $p<0.001)$. Additionally, it was observed that the market knowledge's total effect on the

Table 2. Mediation effects and results of testing hypotheses H1-H4

\begin{tabular}{|c|c|c|c|}
\hline $\begin{array}{l}\text { Scope of Market Knowledge's Effects } \\
\text { on New Product Outcomes }\end{array}$ & $\begin{array}{c}\text { Estimate } \\
\text { (Standardised) }\end{array}$ & $p$-value & $\begin{array}{l}\text { Hypotheses' } \\
\text { Verification }\end{array}$ \\
\hline \multicolumn{4}{|l|}{$\begin{array}{l}\text { Effects from market knowledge scope on product } \\
\text { competitive advantage }\end{array}$} \\
\hline Total effect & 0.285 & 0.000 & \\
\hline H3: Total indirect & 0.322 & 0.000 & Supported \\
\hline \multicolumn{4}{|l|}{ Specific indirect effects } \\
\hline $\begin{array}{l}\text { Market knowledge } \rightarrow \text { Product meaningfulness } \rightarrow \\
\text { Product competitive advantage }\end{array}$ & 0.100 & 0.002 & \\
\hline $\begin{array}{l}\text { Market knowledge } \rightarrow \text { Product novelty } \rightarrow \text { Product } \\
\text { competitive advantage }\end{array}$ & 0.222 & 0.000 & \\
\hline \multicolumn{4}{|l|}{ Direct effect } \\
\hline $\begin{array}{l}\text { H1: Market knowledge } \rightarrow \text { Product competitive } \\
\text { advantage }\end{array}$ & -0.037 & 0.661 & Not supported \\
\hline \multicolumn{4}{|l|}{$\begin{array}{l}\text { Effects from market knowledge scope on product } \\
\text { commercial performance }\end{array}$} \\
\hline Total effect & 0.425 & 0.000 & \\
\hline H4: Total indirect & 0.108 & 0.014 & Supported \\
\hline \multicolumn{4}{|l|}{ Specific indirect effects } \\
\hline $\begin{array}{l}\text { Market knowledge } \rightarrow \text { Product meaningfulness } \rightarrow \\
\text { Product commercial performance }\end{array}$ & 0.067 & 0.035 & \\
\hline $\begin{array}{l}\text { Market knowledge } \rightarrow \text { Product novelty } \rightarrow \text { Product } \\
\text { commercial performance }\end{array}$ & 0.041 & 0.237 & \\
\hline \multicolumn{4}{|l|}{ Direct effect } \\
\hline $\begin{array}{l}\text { H2: Market knowledge } \rightarrow \text { Product commercial } \\
\text { performance }\end{array}$ & 0.317 & 0.000 & Supported \\
\hline
\end{tabular}


product's competitive factor through product creativity was significant and positive $(\beta=$ $0.285, p<0.001)$. The model explained approximately 26.7 per cent of the variance in product competitive advantage, as the coefficient of determination $\left(\mathrm{R}^{2}\right)$ equalled 0.267 for this factor.

Regarding the relationship between the scope of market knowledge and a new product's commercial performance, Table 2 reveals that market knowledge had a significant, positive direct effect on a new product's commercial success $(\beta=0.317, p<0.001)$, thus supporting Hypothesis 2. Additionally, Hypothesis 4 is supported because, as expected, market knowledge's total indirect effect on the commercial performance construct through the product's meaningfulness and novelty is positive and significant $(\beta=0.108, p<0.05)$. However, an examination of the two parallel, specific indirect effects, which constitutes the overall effect, revealed that in this case both were positive, but only mediation through the new product's meaningfulness was significant $(\beta=0.067, p<0.05$ ), while this was insignificant through new product novelty $(\beta=0.041, p>0.05)$. In this mediation, the market knowledge's overall effect on a new product's commercial success was also significant and positive $(\beta=0.425, p<$ 0.001). The coefficient of determination $\left(\mathrm{R}^{2}\right)$ for the product's commercial success was 0.201 , and hence, the model explained 20.1 per cent of the variance in this variable.

In addition to testing the hypotheses, the market knowledge's overall effect on a product's competitive advantage was compared to the market knowledge's total effect on a new product's commercial success through both dimensions of new product creativity. The result of Wald's chi-square test revealed that these effects are not equal: $\chi^{2}(1)=11.478, p<0.001$. As both effects were significant and positive, it was observed that the first total effect, or the market knowledge's influence on a new product's commercial success through product creativity, was stronger than the latter, or from market knowledge to product competitive advantage through product creativity.

\section{Discussion and interpretation of results}

Regarding this work's theoretical contribution, the findings revealed two somewhat different mediating mechanisms between market knowledge and the two new product outcomes through product creativity. The following situation was observed in the first model, in which the focal endogenous variable is a new product's competitive advantage: The scope of market knowledge is likely to indirectly affect a new product's competitive advantage through both dimensions of marketing creativity - a new product's meaningfulness and its novelty. This result parallels both the RBV theory and Amabile and Pratt's (2016) model regarding creativity and innovation in organisations. This is because, on the one hand, the RBV theory posits that knowledge of customers, competitors and other market aspects is a specific company's resource, along with the necessary expertise in the product category domain according to the model of creativity and innovation. This knowledge in NPD allows companies to achieve both dimensions of creative output: useful, novel product innovation. Further, both these creative dimensions - meaningfulness and novelty in product innovation - should consequently result in a superior new product compared to competitors' offerings. However, the scope of market knowledge does not exhibit a direct impact on a new product's competitive advantage, as this effect is overshadowed by the two mediators representing new product creativity. 
Therefore, the overall effect between market knowledge and a new product's competitive advantage is a phenomenon that includes two relationships in a strict sequence. It may be said that in the first step, the scope of market knowledge positively impacts a new product's novelty and meaningfulness; in the second step, these creative outputs positively affect a new product's competitive advantage. These mediators of new product creativity convert the scope of market knowledge into the product's competitive advantage in NPD.

The second mediating mechanism, in which a new product's commercial success is the final result, is as follows. A total indirect effect tends to exist between the scope of market knowledge and a new product's commercial performance through product creativity, but this occurs due to the indirect specific effect through the new product's meaningfulness. Therefore, the scope of market knowledge enhances the product's meaningfulness and novelty, but only the first creative dimension significantly impacts the product's commercial success. Further, only a new product's usefulness (or appropriateness) for customers is likely to increase its commercial success. This link is logical and mirrors results in existing literature (Amabile \& Pratt, 2016; Im \& Workman, 2004). However, it seems that the novelty of product innovation does not affect the new product's commercial performance. This might occur due to a problem known in innovation literature regarding such various barriers as product newness, which affect users' potential adoption of an innovation (Crawford \& Di Benedetto, 2011). However, even if market knowledge is not transferred to the product's commercial success through the novelty of product innovation, the overall indirect effect through new product creativity tends to operate positively because of a positive transmission through the product's meaningfulness. Additionally, apart from the indirect effect, it looks like the scope of market knowledge has a positive and quite strong direct impact on a new product's commercial success. This might be because market knowledge in NPD is widely used not only to generate a creative new product, but also to perform other actions associated with NPD. One example of these actions is the marketing support program implemented during a new product's commercialisation, which is an important factor in its eventual commercial success (Crawford \& Di Benedetto, 2011). Another example is the industrial relationship between buyer and seller, which sometimes assumes the form of a written contract. Therefore, the new product as well as its accompanying actions are likely to influence its commercial success. It is assumed that although these actions are not included in this study's conceptual model, they take the form of a direct relationship.

Additionally, this study's results indicate that the total effect between market knowledge and a new product's commercial performance is stronger than when a new product's competitive advantage is the final outcome of mediation. This might be because this knowledge is primarily used in the former situation to create a product that provides greater value for customers, while this knowledge is additionally applied in the latter situation to perform different product-related operations. However, this issue requires further exploration.

The following managerial implications can be made relative to this study's results. First, NPD managers aiming to achieve a strong competitive advantage for a new product should enhance their knowledge of the new product market in enhancing the new product creativity. Greater market knowledge in NPD will increase its usefulness and novelty for potential buyers. In turn, the product's creative dimensions are necessary; these will offer superior 
value for customers and create the product's competitive advantage. Second, it is recommended that managers increase their market knowledge for a new product to attain commercial success, as this knowledge will indirectly transfer to this success through the new product's meaningfulness. The latter means that the new product is appropriate or useful for prospective customers, and only this dimension of the two creative factors considered is a "vehicle" that is likely to lead to a new product's high commercial performance. The novelty of a product's innovation seems to have no effect on its commercial success, as customers may sometimes perceive this as problematic; thus, it is recommended that managers to create more customer-friendly products or educate consumers so they might more easily adopt such innovations. Third, as market knowledge tends to directly affect a new product's commercial performance, an increase in this knowledge will improve this outcome. Market knowledge is also necessary to invent different actions that might support the new product's commercialisation. Most likely, this direct link captures this phenomenon; therefore, managers should consider developing superior marketing support for a new product. The product's commercial success is based on the new product itself and the operations that support it.

\section{Conclusions}

This study's results indicate that the scope of market knowledge in NPD transfers to both new product outcomes - a new product's competitive advantage and its commercial success - through new product creativity. However, the transmission mechanisms differ, and their overall results are not the same. For example, market knowledge in the first mediation, in which the focal endogenous variable is the product's competitive advantage, transfers to this outcome only through the indirect effects created by both dimensions of new product creativity: its novelty and meaningfulness. This relationship's direct effect is not significant, which means that an increase in market knowledge in NPD is likely to result in a more creative new product; this subsequently should affect the product's competitive advantage. Alternatively, the second mediation, in which the final variable is the product's commercial success, seems to exhibit both direct and indirect relationships between the scope of market knowledge and success, but only through product meaningfulness as a sole mediator, and no significant, indirect link exists through product novelty. Therefore, the product meaningfulness dimension explains a new product's commercial success rather than product novelty, which might be an obstacle for customers in terms of their inclination to adopt innovation. Additionally, the existing direct effect includes some other factors not covered in this work that could convert market knowledge into a product's commercial success.

Several limitations exist in this study. The first limitation involves measuring both new product outcomes as cognitive perceptual variables. This attitude was adopted as objective measures were difficult or impossible to obtain; firms typically perceive information on new product performance as confidential. Cognitive perceptual variables were used in this situation, as these types of measures highly correlate with objective measures of performance (Atuahene-Gima \& Li, 2004; Dess \& Robinson, 1984; Wall et al., 2004) and cognitive performance measurement is common in NPD (e.g. Claudy et al., 2016; Kim et al., 2013; Nakata et al., 2018; Zhang et al., 2015). A second limitation is that all of the sampling units 
were derived from a group of firms with high R\&D intensity, namely medium-high- and high-technology companies, from one country; the specific context of this population can influence the findings' generalisability. A third limitation is that the investigated conceptual model was not cross-validated through a multi-group analysis. It is suggested that future studies test the model in this work with a sample from other industries, such as those with low R\&D intensity, or verify the model using a multi-group analysis across different countries. A fourth limitation is that this study's model only partially explains the variances in the two new product performance factors, as other variables should also be examined. Although important in NPD, only one determinant of creativity (market knowledge), and two mediators describing a creative product were used for brevity. Future research is recommended to test the other determinants of creativity that represent other skills in the task domain than market knowledge, such as skills in multiple domains, or variables that express the intrinsic motivation to perform a task or creativity-relevant processes (Amabile \& Pratt, 2016). Future research could also apply other mediators aside from describing a creative product, such as creative marketing programs that accompany NPD or the industry relationships with key buyers. Therefore, subsequent studies may address mediation processes other than those explored in this work that aim to explain variances in new product outcomes.

\section{Acknowledgements}

The author has no acknowledgements.

\section{Funding}

This work was supported by Faculty of Management and Economics, Gdansk University of Technology under funding number DS 032364.

\section{Author contributions}

The author performed the whole study and wrote the manuscript.

\section{Disclosure statement}

The author has no competing financial, professional, or personal interests from other parties.

\section{References}

Amabile, T. M. (1982). Social psychology of creativity: A consensual assessment technique. Journal of Personality and Social Psychology, 45(2), 357-376. https://doi.org/10.1037//0022-3514.43.5.997

Amabile, T. M., \& Pratt, M. G. (2016). The dynamic componential model of creativity and innovation in organizations: Making progress, making meaning. Research in Organizational Behavior, 36, $157-$ 183. https://doi.org/10.1016/j.riob.2016.10.001 
Anderson, J. C., \& Gerbing, D. W. (1988). Structural equation modeling in practice: A review and recommended two-step approach. Psychological Bulletin, 103(3), 411-423.

https://doi.org/10.1037/0033-2909.103.3.411

Andrews, J., \& Smith, D. C. (1996). In search of the marketing imagination: Factors affecting the creativity of marketing programs for mature products. Journal of Marketing Research, 33(2), 174-187. https://doi.org/10.2307/3152145

Armstrong, J. S., \& Overton, T. S. (1977). Estimating nonresponse bias in mail surveys. Journal of Marketing Research, 14(3), 396. https://doi.org/10.2307/3150783

Atuahene-Gima, K. (1995). An exploratory analysis of the impact of market orientation on new product performance: A contingency approach. Journal of Product Innovation Management, 12(4), 275-293. https://doi.org/10.1016/0737-6782(95)00027-Q

Atuahene-Gima, K. (2005). Resolving the capability: Rigidity paradox in new product innovation. Journal of Marketing, 69(4), 61-83. https://doi.org/10.1509/jmkg.2005.69.4.61

Atuahene-Gima, K., \& Li, H. (2004). Strategic decision comprehensiveness and new product development outcomes in new technology ventures. Academy of Management Journal, 47(4), 583-597. https://doi.org/10.2307/20159603

Atuahene-Gima, K., \& Wei, Y. S. (2011). The vital role of problem-solving competence in new product success. Journal of Product Innovation Management, 28(1), 81-98.

https://doi.org/10.1111/j.1540-5885.2010.00782.x

Bagozzi, R. P., \& Yi, Y. (2012). Specification, evaluation, and interpretation of structural equation models. Journal of the Academy of Marketing Science, 40(1), 8-34.

https://doi.org/10.1007/s11747-011-0278-X

Bao, Y., Sheng, S., \& Zhou, K. Z. (2012). Network-based market knowledge and product innovativeness. Marketing Letters, 23(1), 309-324. https://doi.org/10.1007/s11002-011-9155-0

Barney, J. (1991). Firm resources and sustained competitive advantage. Journal of Management, 17(1), 99-120. https://doi.org/10.1177/014920639101700108

Baron, R. M., \& Kenny, D. A. (1986). The moderator-mediator variable distinction in social psychological research: Conceptual, strategic, and statistical considerations. Journal of Personality and Social Psychology, 51(6), 1173-1182. https://doi.org/10.1037/0022-3514.51.6.1173

Bentler, P. M., \& Chou, C. P. (1987). Practical issues in structural modeling. Sociological Methods \& Research, 16(1), 78-117. https://doi.org/10.1177/0049124187016001004

Brown, T. A., \& Moore, M. T. (2012). Confirmatory factor analysis. In R. Hoyle (Ed.), Handbook of structural equation modeling (pp. 361-379). New York: Guilford Press.

Bruner, J. (1962). The conditions of creativity. In H. E. Gruber, G. Terrell, \& M. Wertheimer (Eds.), Contemporary approaches to creative thinking. New York: Atherton Press.

Claudy, M. C., Peterson, M., \& Pagell, M. (2016). The roles of sustainability orientation and market knowledge competence in new product development success. Journal of Product Innovation Management, 33, 72-85. https://doi.org/10.1111/jpim.12343

Cooper, R. G. (2019). The drivers of success in new-product development. Industrial Marketing Management, 76, 36-47. https://doi.org/10.1016/j.indmarman.2018.07.005

Crawford, M., \& Di Benedetto, A. (2011). New products management (10th ed.). New York: McGrawHill Irwin. https://doi.org/10.1016/0923-4748(93)90075-T

Dabrowski, D. (2018). Sources of market information, its quality and new product financial performance. Engineering Economics, 29(1). https://doi.org/10.5755/j01.ee.29.1.13405

De Luca, L. M., \& Atuahene-Gima, K. (2007). Market knowledge dimensions and cross-functional collaboration: Examining the different routes to product innovation performance. Journal of Marketing, 71(January), 95-112. https://doi.org/10.1509/jmkg.71.1.95 
Dess, G. G., \& Robinson, R. B. (1984). Measuring organizational performance in the absence of objective measures: The case of the privately-held firm and conglomerate business unit. Strategic Management Journal, 5(32), 265-273. https://doi.org/10.1002/smj.4250050306

Dhebar, A. (2016). Bringing new high-technology products to market: Six perils awaiting marketers. Business Horizons, 59(6), 713-722. https://doi.org/10.1016/j.bushor.2016.08.006

Evanschitzky, H., Eisend, M., Calantone, R. J., \& Jiang, Y. (2012). Success factors of product innovation: An updated meta-analysis. Journal of Product Innovation Management, 29(1994), 21-37. https://doi.org/10.1111/j.1540-5885.2012.00964.x

Ferreras-Méndez, J. L., Newell, S., Fernández-Mesa, A., \& Alegre, J. (2015). Depth and breadth of external knowledge search and performance: The mediating role of absorptive capacity. Industrial Marketing Management, 47, 86-97. https://doi.org/10.1016/j.indmarman.2015.02.038

Ford, J. K., MacCullum, R. C., \& Tait, M. (1986). The application of exploratory factor analysis in applied psychology: A critical review and analysis. Personnel Psychology, 39(2), 291-314. https://doi.org/10.1111/j.1744-6570.1986.tb00583.x

Fornell, C., \& Larcker, D. F. (1981). Evaluating structural equation models with unobservable variables and measurement error. Journal of Marketing Research, 18(1), 39-50. https://doi.org/10.2307/3151312

Ginevičius, R., \& Korsakiene, R. (2005). The knowledge-based economy in Lithuania: Analysis of tendencies. Journal of Business Economics and Management, 6(4), 231-239. https://doi.org/10.3846/16111699.2005.9636113

Ginevičius, R., Podvezko, V., \& Ginevičius, A. (2013). Quantitative evaluation of enterprise marketing activities. Journal of Business Economics and Management, 14(1), 200-212. https://doi.org/10.3846/16111699.2012.731143

Guo, R., Cai, L., \& Fei, Y. (2019). Knowledge integration methods, product innovation and high-tech new venture performance in China. Technology Analysis and Strategic Management, 31(3), 306-318. https://doi.org/10.1080/09537325.2018.1500688

Hatzichronoglou, T. (1997). Revision of the high-technology sector and product classification. OECD Science, Technology and Industry Working Papers, 1997/02, 26. https://doi.org/10.1787/134337307632

Hayes, A. F., \& Rockwood, N. J. (2017). Regression-based statistical mediation and moderation analysis in clinical research: Observations, recommendations, and implementation. Behaviour Research and Therapy, 98, 39-57. https://doi.org/10.1016/j.brat.2016.11.001

Henard, D. H., \& Szymanski, D. M. (2001). Why some new products are more successful than others. Journal of Marketing Research, 38(3), 362-375. https://doi.org/10.1509/jmkr.38.3.362.18861

Hertenstein, J. H., \& Platf, M. B. (2000). Performance measures and management control in new product development. Accounting Horizons, 14(3), 303-323. https://doi.org/10.2308/acch.2000.14.3.303

Hu, L. T., \& Bentler, P. M. (1999). Cutoff criteria for fit indexes in covariance structure analysis: Conventional criteria versus new alternatives. Structural Equation Modeling, 6(1), 1-55. https://doi.org/10.1080/10705519909540118

Hultink, E. J., Talke, K., Griffin, A., \& Veldhuizen, E. (2011). Market information processing in new product development: The importance of process interdependency and data quality. IEEE Transactions on Engineering Management, 58(2), 199-211. https://doi.org/10.1109/TEM.2009.2034254

Im, S., Hussain, M., \& Sengupta, S. (2008). Testing interaction effects of the dimensions of market orientation on marketing program creativity. Journal of Business Research, 61(8), 859-867. https:// doi.org/10.1016/j.jbusres.2007.09.003

Im, S., Montoya, M. M., \& Workman, J. P. (2013). Antecedents and consequences of creativity in product innovation teams. Journal of Product Innovation Management, 30(1), 170-185. https://doi.org/10.1111/j.1540-5885.2012.00887.x

Im, S., \& Workman, J. P. (2004). Market orientation, creativity, and new product performance in hightechnology firms. Journal of Marketing, 68(April), 114-132.

https://doi.org/10.1509/jmkg.68.2.114.27788 
Jin, J. L., Shu, C., \& Zhou, K. Z. (2019). Product newness and product performance in new ventures: Contingent roles of market knowledge breadth and tacitness. Industrial Marketing Management, 76, 231-241. https://doi.org/10.1016/j.indmarman.2018.08.009

Jose, P. E. (2013). Doing statistical mediation and moderation. New York: The Guilford Press.

Kim, N., Im, S., \& Slater, S. F. (2013). Impact of knowledge type and strategic orientation on new product creativity and advantage in high-technology firms. Journal of Product Innovation Management, 30(1), 136-153. https://doi.org/10.1111/j.1540-5885.2012.00992.x

Kline, R. B. (2012). Assumptions in structural equation modeling. In R. H. Hoyle (Ed.), Handbook of structural equation modeling (pp. 111-125). New York: The Guilford Press.

Lee, H., \& Markham, S. K. (2016). PDMA comparative performance assessment study (CPAS): Methods and future research directions. Journal of Product Innovation Management, 33, 3-19. https://doi.org/10.1111/jpim.12358

Li, T., \& Calantone, R. J. (1998). The impact of market knowledge competence on new product advantage: Conceptualization and empirical examination. Journal of Marketing, 62(4), 13. https://doi.org/10.2307/1252284

Lin, R. J., Che, R. H., \& Ting, C. Y. (2012). Turning knowledge management into innovation in the high-tech industry. Industrial Management \& Data Systems, 112(1), 42-63. https://doi.org/10.1108/02635571211193635

López-Cabarcos, M. Á., Srinivasan, S., Göttling-Oliveira-Monteiro, S., \& Vázquez-Rodríguez, P. (2019). Tacit knowledge and firm performance relationship. The role of product innovation and the firm level capabilities. Journal of Business Economics and Management, 20(2), 330-350. https://doi.org/10.3846/jbem.2019.9590

Malhotra, N. K., Schaller, T. K., \& Patil, A. (2017). Common method variance in advertising research: When to be concerned and how to control for it. Journal of Advertising, 46(1), 193-212. https://doi.org/10.1080/00913367.2016.1252287

Merenda, P. F. (1997). A guide to the proper use of factor analysis in the conduct and reporting of research: Pitfalls to avoid. Measurement and Evaluation in Counseling and Development, 30(3), 156-164.

Montoya-Weiss, M. M., \& Calantone, R. (1994). Determinants of new product performance: A review and meta-analysis. Journal of Product Innovation Management, 11(November), 397-417. https://doi.org/10.1016/0737-6782(94)90029-9

Muthén, B. O., Muthén, L., \& Asparouhov, T. (2016). Regression and mediation analysis using Mplus. Los Angeles: Muthen \& Muthen.

Nakata, C., Rubera, G., Im, S., Pae, J. H., Lee, H. J., Onzo, N., \& Park, H. (2018). New product creativity antecedents and consequences: Evidence from South Korea, Japan, and China. Journal of Product Innovation Management, 35(6), 939-959. https://doi.org/10.1111/jpim.12436

Narver, J. C., \& Slater, S. F. (1990). The effect of a market orientation on business profitability. Journal of Marketing, 54(4), 20-35. https://doi.org/10.2307/1251757

OECD. (2015). OECD science, technology and industry scoreboard 2015: Innovation for growth and society. https://doi.org/10.1787/sti_scoreboard-2015-en

Ozkaya, H. E., Droge, C., Hult, G. T. M., Calantone, R., \& Ozkaya, E. (2015). Market orientation, knowledge competence, and innovation. International Journal of Research in Marketing, 32(3), 309-318. https://doi.org/10.1016/j.ijresmar.2014.10.004

Slater, S. F., Hult, G. T. M., \& Olson, E. M. (2010). Factors influencing the relative importance of marketing strategy creativity and marketing strategy implementation effectiveness. Industrial Marketing Management, 39, 551-559. https://doi.org/10.1016/j.indmarman.2008.03.007

Stankevičienė, J., Levickaitė, R., Braškute, M., \& Noreikaitė, E. (2011). Creative ecologies: Developing and managing new concepts of creative economy. Business, Management and Education, 9(2), 277294. https://doi.org/10.3846/bme.2011.19 
Teece, D., Pisano, G., \& Shuen, A. (1997). Dynamic capabilities and strategic management. Strategic Management Journal, 18(7), 509-533. https://doi.org/10.1016/B978-0-7506-7088-3.50009-7

Wade, M., \& Hulland, J. (2004). The resource-based view and information systems research: Review, extension, and suggestions for future research. MIS Quarterly, 28(1), 107-142. https://doi.org/10.2307/25148626

Wall, T. D., Michine, J., Patterson, M., Wood, S. J., Sheehan, M., Clegg, C., \& Wesr, M. (2004). On the validity of subjective measures of company performance. Personnel Psychology, 57, 95-118. https://doi.org/10.1159/000172511

Wernerfelt, B. (1984). A resource-based view of the firm. Strategic Management Journal, 5(Apr-Jun), 171-180. https://doi.org/10.1002/smj.4250050207

West, S. G., Taylor, A. B., \& Wu, W. (2012). Model fit and model selection in structural equation modeling. In R. Hoyle (Ed.), Handbook of structural equation modeling (pp. 209-231). New York: The Guilford Press.

Yuan, L., \& Chen, X. (2015). Managerial learning and new product innovativeness in high-tech industries: Curvilinear effect and the role of multilevel institutional support. Industrial Marketing Management, 50, 51-59. https://doi.org/10.1016/j.indmarman.2015.05.021

Zhang, H., Wu, F., \& Cui, A. S. (2015). Balancing market exploration and market exploitation in product innovation: A contingency perspective. International Journal of Research in Marketing, 32(3), 297-308. https://doi.org/10.1016/j.ijresmar.2015.03.004

\section{APPENDIX}

Table A1. Results of confirmatory factor analysis, construct reliability (CR), and average variance extracted (AVE)

\begin{tabular}{|l|l|l|l|l|}
\hline \multicolumn{1}{|c|}{ Five Factors and Scale Items } & $\lambda^{*}$ & $t$-values & CR & AVE \\
\hline $\begin{array}{l}\text { Market knowledge } \\
\text { In comparison to competitors our knowledge in this new } \\
\text { product development ... }\end{array}$ & & & 0.834 & 0.558 \\
\hline concerned many different aspects of the market & 0.767 & 29.37 & & \\
\hline was extensive about customers & 0.713 & 20.71 & & \\
\hline was thorough about our key competitors & 0.710 & 18.88 & & \\
\hline $\begin{array}{l}\text { was characterised by a deep understanding of market } \\
\text { mechanisms }\end{array}$ & 0.794 & 32.65 & & \\
\hline $\begin{array}{l}\text { Product meaningfulness } \\
\text { Compared to your competitors, this new product ... }\end{array}$ & & & 0.895 & 0.681 \\
\hline is relevant to customers' needs and expectations & 0.833 & 37.47 & & \\
\hline is considered suitable for customers' desires & 0.837 & 36.77 & & \\
\hline is appropriate for customers' needs and expectations & 0.869 & 41.04 & & \\
\hline is useful for customers & 0.759 & 20.17 & & \\
\hline $\begin{array}{l}\text { Product novelty } \\
\text { Compared to your competitors, this new product ... }\end{array}$ & & & 0.857 & 0.603 \\
\hline is really "out of the ordinary" & 0.836 & 34.35 & & \\
\hline can be considered revolutionary & 0.859 & 42.88 & & \\
\hline is stimulating & 0.751 & 27.11 & & \\
\hline
\end{tabular}


End of Table A1

\begin{tabular}{|l|c|c|c|c|}
\hline \multicolumn{1}{|c|}{ Five Factors and Scale Items } & $\lambda^{*}$ & $t$-values & CR & AVE \\
\hline demonstrates unconventional problem-solving & 0.640 & 16.87 & & \\
\hline $\begin{array}{l}\text { Product competitive advantage (three-item semantic } \\
\text { differential scale) } \\
\text { Relative to competing products in the market, } \\
\text { this new product ... }\end{array}$ & & & 0.851 & 0.656 \\
\hline has inferior versus superior quality & 0.799 & 19.64 & & \\
\hline is not at all differentiated versus highly differentiated & 0.755 & 15.86 & & \\
\hline is much worse versus much better & 0.872 & 31.42 & & \\
\hline $\begin{array}{l}\text { Product commercial performance } \\
\text { This new product achieved ... }\end{array}$ & & & 0.915 & 0.731 \\
\hline unit sales goals & 0.920 & 71.32 & & \\
\hline revenue sales goals & 0.912 & 60.11 & & \\
\hline market share goals & 0.826 & 39.06 & & \\
\hline sufficient sales as a percentage of total company sales & 0.751 & 23.80 & & \\
\hline
\end{tabular}

Note: All items are measured by a seven-point Likert-type scale; $\lambda$ - standardised loadings;

* all standardised loadings are significant at $p<0.001$. 